\title{
Quality of life in young onset dementia: an updated systematic review
}

\author{
Qualidade de vida na demência de início precoce: uma revisão sistemática \\ atualizada
} Maria Alice Tourinho Baptista, ${ }^{1}$ Raquel Luiza Santos, ${ }^{1}$ Nathália Kimura, ${ }^{1}$ Isabel Barbeito Lacerda, ${ }^{1}$ Aud Johannenssen, $^{2}$
Maria Lage Barca, ${ }^{2}$ Knut Engedal, ${ }^{2}$ Marcia Cristina Nascimento Dourado ${ }^{1}$

\begin{abstract}
Introduction: Young onset dementia (YOD) develops before 65 years of age and has specific age-related adverse consequences for quality of life (QoL). We systematically examined factors related to the QoL of people with YOD and their caregivers.

Method: This systematic review used the PRISMA methodology. The literature search was undertaken on July 5, 2015, using Cochrane, PubMed, SciELO, PsycINFO, Scopus and Thomson Reuters Web of Science electronic databases. The search keywords included early onset and young onset combined with, dementia, Alzheimer, vascular dementia, mixed dementia, frontotemporal dementia, quality of life, well-being and unmet needs. Nine studies were included. We revised objectives, study design, sample, instruments and results related to QoL.

Results: People with YOD rated their own QoL significantly higher than their caregivers. Greater awareness of disease among people with YOD is associated with better QoL in caregivers. A relationship was found between unmet needs and daytime activities, lack of companionship and difficulties with memory. Issues associated with unmet needs were prolonged time to diagnosis, available health services and lack of caregiver's own future perspective.

Conclusion: Consideration should be given to conducting investigations with more homogeneous samples and use of a clear concept of QoL. The present study highlights the need for future research in a wider range of countries, using instruments specifically for YOD. It would be interesting if studies could trace parallels with late onset dementia groups.
\end{abstract}

Keywords: Young onset dementia, quality of life, well-being, unmet needs, people with young onset dementia, caregivers.

\section{Resumo}

Introdução: A demência de início precoce se desenvolve antes dos 65 anos e possui consequências adversas específicas relacionadas à idade para a qualidade de vida (QV). Nós examinamos de forma sistemática fatores ligados à QV de pessoas com demência de início precoce e seus cuidadores.

Método: Foi utilizada a metodologia PRISMA, com busca nas bases de dados Cochrane, PubMed, SciELO, PsycINFO, Scopus e Thomson Reuters Web of Science electronic em 5 de julho de 2015. Foi utilizada a palavra-chave início precoce combinada com demência, Alzheimer, demência vascular, demência mista, demência frontotemporal, qualidade de vida, bem-estar e necessidades não atendidas. Nove estudos foram incluídos. Foram revisados os objetivos, desenho, amostra, instrumentos e resultados relacionados à QV.

Resultados: Pessoas com demência de início precoce pontuaram sua própria QV significantemente mais alta que seus cuidadores. A maior consciência da doença entre essas pessoas é associada com melhor QV dos cuidadores. Foi encontrada relação entre necessidades não atendidas e atividades diárias, falta de companhia e dificuldades com a memória. A demora na definição do diagnóstico, os serviços de saúde disponíveis e a falta de perspectivas futuras do cuidador foram fatores associados às necessidades não atendidas.

Conclusão: Deve-se considerar a possibilidade de conduzir investigações com amostras mais homogêneas e um conceito mais claro de QV. O presente estudo chama atenção para a necessidade de pesquisas em mais países, utilizando instrumentos específicos para pessoas com demência de início precoce. Seria interessante se estudos pudessem traçar paralelos com grupos de início tardio.

Descritores: Demência de início precoce, qualidade de vida, bem-estar, necessidades não atendidas, pessoas com demência de início precoce, cuidadores.

\footnotetext{
${ }^{1}$ Centro de Doença de Alzheimer e outros Transtornos Mentais na Velhice, Instituto de Psiquiatria, Universidade Federal do Rio de Janeiro (UFRJ), Rio de Janeiro, RJ, Brazil. ${ }^{2}$ Norwegian Centre for Aging and Health, Vestfold Health Trust, Tønsberg, Norway.

Financial support: Conselho Nacional de Desenvolvimento Científico e Tecnológico (CNPq).

Submitted Aug 21 2015, accepted for publication Nov 28 2015. No conflicts of interest declared concerning the publication of this article.

Suggested citation: Baptista MA, Santos RL, Kimura N, Lacerda IB, Johannenssen A, Barca ML, et al. Quality of life in young onset dementia: an updated systematic review Trends Psychiatry Psychother. 2016;38(1):6-13. http://dx.doi.org/10.1590/2237-6089-2015-0049
} 


\section{Introduction}

Young onset dementia (YOD) is defined as a dementia disorder that develops before 65 years of age. ${ }^{1-5}$ Estimated prevalence rates of YOD range from 42.3 to 54 per 100,000 cases of dementia. ${ }^{6}$ Alzheimer's disease is the most frequent cause, followed by vascular and frontotemporal dementia, respectively. ${ }^{1-3,7,8}$ Neuropsychological impairments and behavioral changes may vary according to the specifics of each dementia disorder. In cases of young onset Alzheimer's disease $(A D)$, for instance, there is a greater initial loss of cognitive abilities. ${ }^{8}$ These people are more likely to present deficits in attention, visuospatial function and language. ${ }^{8}$ Conversely, in late onset Alzheimer's disease, short-term memory loss is usually prominent. ${ }^{8}$ Moreover, people with young onset Alzheimer's disease exhibit a faster rate of decline compared to people with late onset AD. 7,9 In general, YOD has specific features that may be a challenge for diagnosis and management and for organization of appropriate health services.

Young onset dementia is an important psychosocial and medical health problem with specific age-related adverse consequences for both younger individuals and their families. ${ }^{10}$ Usually, these individuals have more neuropsychiatric symptoms, especially in frontotemporal dementia, where the initial poor executive function is often overlooked. ${ }^{3}$ This can lead physicians to incorrectly diagnose a psychiatric disorder, causing inadequate treatment and delay before the correct diagnosis is made. ${ }^{3,8,11}$ Furthermore, the onset of young onset neurodegenerative dementia is usually insidious and the first signs tend to be ignored or explained away as stress or fatigue caused by work or everyday pressures. Dementia is not a disease that one expects to find in younger people, so it may take longer before the first suspicions are raised that a dementia process may be taking place. ${ }^{4,8}$

Typically, individuals with YOD are still in the labor market when the diagnosis is made. ${ }^{12}$ They are usually family providers (which can cause severe economic disruption), still have children and/or dependents, drive vehicles and are physically healthy. $1,4,7,8,12$ The life changes involved in the onset of the disease and a more preserved awareness ${ }^{12}$ can cause greater psychosocial impact than in late onset dementia (LOD). The marked age differences make it difficult for people with YOD to integrate into mainstream dementia services. ${ }^{1}$

Considering the particular issues of YOD, their carers are expected to have specific problems, such as life stage challenges, diagnostic difficulties, problems coping with symptoms and relationship changes, including issues surrounding intimacy and sexuality for partners. ${ }^{9}$ These aspects suggest that the needs of this group of people and their families may be different, leading to a considerable impairment in their quality of life (QoL) and sense of well-being.

Quality of life, well-being and unmet needs are closely related concepts. ${ }^{13}$ They are complex because they involve a subjective perception related to physical, social and psychological variables. Needs that are not fulfilled are likely to have an adverse effect on people with dementia and caregiver well-being and may negatively influence their QoL. ${ }^{14}$ Therefore, in addition to assessing objective patient-related measures (including memory and functional abilities), environmental factors such as social support and material conditions, value systems and coping styles also play a role in the equation. ${ }^{15,16}$ Studies report that, in dementia, aspects that impact on well-being and perception of QoL are age, depressed mood, quality of relationship of the dyad, awareness of the disease and neuropsychiatric symptoms, while difficulties with cognitive and functional abilities do not normally interfere. ${ }^{15}$ However, these findings are related to LOD and there are concerns about how the specific problems of YOD affect the QoL of people with dementia and their caregivers.

Within this context, this systematic review aims to obtain and compile more precise, up-to-date information on the factors related to QoL, well-being and unmet needs in $\mathrm{YOD}$, in order to enrich the literature on the subject.

\section{Methods}

This systematic review was conducted using the methodology suggested in the Preferred Reporting Items for Systematic Reviews and Meta-Analyses (PRISMA) criteria. ${ }^{17}$ The search for literature was undertaken on July 5, 2015, using Cochrane, PubMed, SciELO, PsycINFO, Scopus and Thomson Reuters Web of Science electronic databases. The search keywords included early onset dementia, young onset dementia, early onset Alzheimer, young onset Alzheimer, early onset vascular dementia, young onset vascular dementia, early onset mixed dementia, young onset mixed dementia, early onset front temporal dementia and young onset frontotemporal dementia, which were combined with quality of life, well-being and unmet needs. We also performed a manual search by revising the reference lists of all papers selected.

The inclusion criteria for articles were as follows: cross-sectional or longitudinal studies, randomized or nonrandomized, with or without a control group, with caregivers and/or people with young onset Alzheimer's disease, vascular dementia, mixed or frontotemporal dementia, at all stages of severity. Systematic reviews 
and opinion papers were excluded, as well as articles which addressed other neurological disorders, psychiatric or late-onset dementias, and those that did not study QoL, well-being or unmet needs.

Initially, all abstracts selected were read by two authors (MATB and MCND). Articles were reviewed taking into account six characteristics: Objectives, interventions, study design, sample, instruments used and results related to the QoL of caregivers and/or people with a diagnosis of YOD. All authors revised the papers selected in order to reach a consensus.

\section{Results}

The Cochrane database was searched to identify systematic reviews with the same theme. We found none. The initial database searches produced 324 articles. Thirteen were found on PsycINFO and 31 on Scopus, 54 were identified on PubMed and 225 on
Thomson Reuters Web of Science and 1 article was found on SciELO. After duplicates were removed ( $\mathrm{n}=$ 180), 146 studies not meeting inclusion criteria were eliminated, leaving seven studies which were selected for inclusion in this systematic review. Two further studies were identified by manually searching the references in the selected articles. Therefore, a final total of nine papers had been selected by the end of this search process (Figure 1 ). Main results are shown in Table 1.

\section{Concepts}

\section{YOD}

Three articles used the term EOD, 22,23,26 one study used the term early onset familial $A D,{ }^{25}$ and most of the papers, five of them, used the term YOD. ${ }^{18-21,24}$ More than half of the papers clearly conceptualize the concept of YOD.

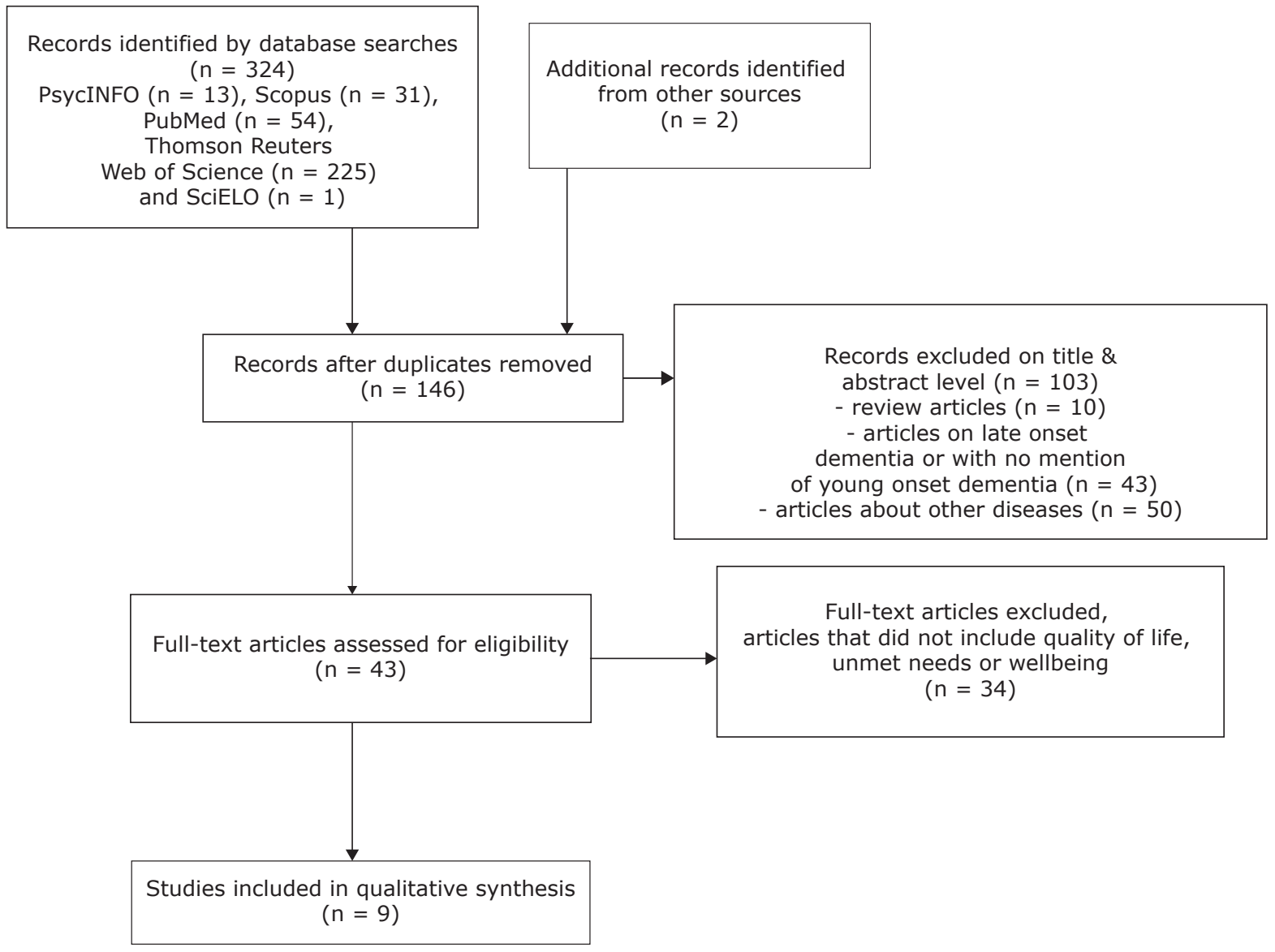

Figure 1 - Flow of information through the different phases of the systematic review 
Table 1 - Characteristics of the studies selected

\begin{tabular}{|c|c|c|c|c|c|c|}
\hline Study & Objectives & Interventions & $\begin{array}{c}\text { Study } \\
\text { design }\end{array}$ & $\begin{array}{c}\text { Sample and } \\
\text { setting }\end{array}$ & $\begin{array}{l}\text { Assessment } \\
\text { methods }\end{array}$ & Main results \\
\hline $\begin{array}{l}\text { Bakker et } \\
\quad \text { al. }{ }^{18}\end{array}$ & $\begin{array}{l}\text { Investigate the } \\
\text { relationship between } \\
\text { HRQOL and unmet } \\
\text { needs in YOD }\end{array}$ & No interventions & $\begin{array}{l}\text { Cross- } \\
\text { sectional }\end{array}$ & $\begin{array}{c}\text { People with } A D, \\
\text { VaD, FTD, MD and } \\
\text { dementia due to } \\
\text { other causes, } \\
n=215 \\
\text { Carers, } n=215 \\
\text { Netherlands }\end{array}$ & $\begin{array}{c}\text { QOL-AD } \\
\text { administered to } \\
\text { patients and the } \\
\text { Dutch version of } \\
\text { RAND-36 Health } \\
\text { Survey and CANE } \\
\text { administered to } \\
\text { carers }\end{array}$ & $\begin{array}{l}\text { PwD's QoL is not } \\
\text { associated with unmet } \\
\text { needs. There is a } \\
\text { relationship between } \\
\text { unmet needs of } \\
\text { PwD and reduced } \\
\text { caregiver's QoL. }\end{array}$ \\
\hline $\begin{array}{l}\text { Bakker et } \\
\quad \text { al. }^{19}\end{array}$ & $\begin{array}{l}\text { Investigate the } \\
\text { needs of care and } \\
\text { its relationship } \\
\text { to the severity of } \\
\text { neuropsychiatric } \\
\text { symptoms }\end{array}$ & No interventions & Longitudinal & $\begin{array}{c}\text { People with } A D, \\
\text { VaD, FTD, MD and } \\
\text { dementia due to } \\
\text { other causes, } \\
n=215 \\
\text { Carers, } n=215 \\
\text { Netherlands }\end{array}$ & CANE & $\begin{array}{l}\text { Caregivers and PwD } \\
\text { agreed on the areas in } \\
\text { which needs occurred. } \\
\text { PwD experienced high } \\
\text { levels of unmet needs } \\
\text { in daytime activities, } \\
\text { social company, } \\
\text { intimate relationships, } \\
\text { and information. }\end{array}$ \\
\hline $\begin{array}{l}\text { Koopmans } \\
\text { et al. }{ }^{20}\end{array}$ & $\begin{array}{l}\text { Investigate PDU in } \\
\text { Dutch community- } \\
\text { dwelling people } \\
\text { with YOD and the } \\
\text { association between } \\
\text { age, gender, dementia } \\
\text { etiology and severity, } \\
\text { symptoms of } \\
\text { depression, disease } \\
\text { awareness, unmet } \\
\text { needs, and type of } \\
\text { neuropsychiatric } \\
\text { symptoms }\end{array}$ & No interventions & $\begin{array}{l}\text { Cross- } \\
\text { sectional }\end{array}$ & $\begin{array}{c}\text { People with } \\
\text { AD, VaD, FTD } \\
\text { and dementia } \\
\text { not otherwise } \\
\text { specified, } \mathrm{n}=198 \\
\text { Netherlands }\end{array}$ & $\begin{array}{l}\text { The Dutch version } \\
\text { of the CANE }\end{array}$ & $\begin{array}{l}\text { The majority of the } \\
\text { sample had three } \\
\text { or more unmet } \\
\text { needs. There was no } \\
\text { association between } \\
\text { unmet needs and PDU. }\end{array}$ \\
\hline $\begin{array}{l}\text { Hewitt et } \\
\text { al. }^{21}\end{array}$ & $\begin{array}{l}\text { Identify the benefits of } \\
\text { a gardening program } \\
\text { in people with YOD }\end{array}$ & $\begin{array}{l}\text { Two gardening } \\
\text { sessions per } \\
\text { week for one } \\
\text { year with } \\
\text { multidisciplinary } \\
\text { team }\end{array}$ & Longitudinal & $\begin{array}{c}\text { People with AD, } \\
\text { MD, FTD and } \\
\text { dementia with } \\
\text { Lewy bodies, } \\
n=12 \\
\text { United Kingdom }\end{array}$ & $\begin{array}{l}\text { Bradford Well- } \\
\text { being Profile }\end{array}$ & $\begin{array}{l}\text { There was a gradual } \\
\text { increase in well- } \\
\text { being indicators over } \\
\text { the duration of the } \\
\text { gardening project. }\end{array}$ \\
\hline $\begin{array}{l}\text { Rosness et } \\
\text { al. } .^{22}\end{array}$ & $\begin{array}{c}\text { Investigate QoL and } \\
\text { depression in carers } \\
\text { living with people with } \\
\text { YOD }\end{array}$ & No interventions & $\begin{array}{l}\text { Cross- } \\
\text { sectional }\end{array}$ & $\begin{array}{c}\text { Carers of people } \\
\text { with AD, FTD, VD } \\
\text { and dementia with } \\
\text { Lewy bodies, } \\
n=49 \\
\text { Norway }\end{array}$ & QoL-AD & $\begin{array}{l}\text { Carers' QoL } \\
\text { corresponds positively } \\
\text { with the increased age } \\
\text { of carers and with } \\
\text { PwD's insight. }\end{array}$ \\
\hline $\begin{array}{l}\text { Bakker et } \\
\text { al. }^{23}\end{array}$ & $\begin{array}{l}\text { Study unmet needs } \\
\text { of YOD individuals } \\
\text { and caregivers, and } \\
\text { explore caregivers' } \\
\text { experiences of } \\
\text { transitions in care and } \\
\text { health care services }\end{array}$ & No interventions & Longitudinal & $\begin{array}{l}\text { One } 59 \text { year-old } \\
\text { AD patient and his } \\
\text { wife (caregiver) } \\
\text { Netherlands }\end{array}$ & $\begin{array}{l}\text { CANE and semi } \\
\text { structured } \\
\text { interviews }\end{array}$ & $\begin{array}{l}\text { PwD and his caregiver } \\
\text { were confronted } \\
\text { with the prolonged } \\
\text { time to diagnosis, } \\
\text { the fit between PwD } \\
\text { and caregiver needs } \\
\text { and the available } \\
\text { health services, the } \\
\text { strain of dedication } \\
\text { to care versus the } \\
\text { caregiver's own future } \\
\text { perspective, and the } \\
\text { need for response of } \\
\text { health care services. }\end{array}$ \\
\hline $\begin{array}{l}\text { Allen et } \\
\text { al. }^{24}\end{array}$ & $\begin{array}{c}\text { Explore the impact of } \\
\text { having a father with } \\
\text { EOD (AD, VD and FTD) } \\
\text { on the well-being of } \\
\text { young people }\end{array}$ & No interventions & $\begin{array}{l}\text { Qualitative } \\
\text { analysis of } \\
\text { interviews }\end{array}$ & $\begin{array}{c}\text { Children aged } 13 \\
\text { to } 23 \text { years old of } \\
\text { people with } A D \text {, } \\
\text { VD and FTD, } \\
n=12 \\
\text { United Kingdom }\end{array}$ & $\begin{array}{l}45-90 \text { minutes } \\
\text { open interviews }\end{array}$ & $\begin{array}{l}\text { Delay in diagnosis } \\
\text { and the difficulty of } \\
\text { dealing with confused } \\
\text { behaviors in agile, } \\
\text { physically well adults } \\
\text { are primary stressors } \\
\text { which had a major } \\
\text { impact on children's } \\
\text { well-being. }\end{array}$ \\
\hline
\end{tabular}




\begin{tabular}{|c|c|c|c|c|c|c|}
\hline $\begin{array}{l}\text { Herrera et } \\
\text { al. }^{25}\end{array}$ & $\begin{array}{l}\text { Describe self-assessed } \\
\text { QoL in a group of } \\
\text { middle-aged adult } \\
\text { carriers and non- } \\
\text { carriers of mutation } \\
\text { E280A in gene } \\
\text { Presenilin } 1 \text { for early } \\
\text { onset familial AD }\end{array}$ & No interventions & $\begin{array}{l}\text { Cross- } \\
\text { sectional }\end{array}$ & $\begin{array}{c}\text { Carriers of the } \\
\text { mutation, } \mathrm{n}=27 \\
\text { Non-carriers, } \\
\mathrm{n}=39 \\
\text { Elderly adults, } \\
\mathrm{n}=96 \\
\text { Colombia }\end{array}$ & WHOQOL-Bref & $\begin{array}{l}\text { Carrying this mutation } \\
\text { did not influence self } \\
\text { assessment of QoL. }\end{array}$ \\
\hline $\begin{array}{l}\text { Williams et } \\
\quad \text { al. }^{26}\end{array}$ & $\begin{array}{l}\text { Compare the incidence } \\
\text { and prevalence of } \\
\text { EOD in Leeds with } \\
\text { the literature; identify } \\
\text { the needs of PwD } \\
\text { and their carers; } \\
\text { examine existing } \\
\text { services and access } \\
\text { to them; identify } \\
\text { gaps and make } \\
\text { recommendations to } \\
\text { improve the provision } \\
\text { of services }\end{array}$ & No interventions & $\begin{array}{l}\text { Cross- } \\
\text { sectional }\end{array}$ & $\begin{array}{c}\text { People with } \\
\text { AD, VD, lobar } \\
\text { dementia, alcohol } \\
\text { related dementia } \\
\text { and other causes, } \\
\mathrm{n}=132 \\
\text { Carers, } \mathrm{n}=49 \\
\text { United Kingdom }\end{array}$ & $\begin{array}{l}\text { Postal survey, } \\
\text { a health needs } \\
\text { assessment and } \\
\text { a semi-structured } \\
\text { interview with } \\
\text { PwD, carers and } \\
\text { professionals }\end{array}$ & $\begin{array}{l}\text { Two-thirds of carers } \\
\text { reported that their } \\
\text { well-being was poor or } \\
\text { very poor; the longer } \\
\text { the length of caring, } \\
\text { the worse their well- } \\
\text { being; PwD pointed } \\
\text { out their distress at } \\
\text { losing: abilities to } \\
\text { read, write, converse } \\
\text { and take part in } \\
\text { everyday life. }\end{array}$ \\
\hline
\end{tabular}

$\overline{A D}=$ Alzheimer's disease; CANE = Camberwell Assessment of Need for the Elderly; D-QOL = The Dementia - Quality of Life instrument; FTD = frontotemporal dementia; $\mathrm{HRQOL}=$ health related quality of life; $\mathrm{QOL}-\mathrm{AD}=$ The Quality of Life - Alzheimer Disease scale; $\mathrm{QOL}=$ quality of life; $\mathrm{MD}=$ mixed dementia; PDU = psychotropic drug use; PWD = people with dementia; WHOQOL-Bref = World Health Organization Quality of Life instrument-Abbreviated version; YOD = young onset dementia; $\mathrm{VaD}=$ vascular dementia.

\section{QoL}

The concept of QoL was assessed in three studies. ${ }^{18,22,25}$ Two studies did not define QoL.18,22 One article defined QoL as the result of an individual valuation process of many dimensions that interact between the person and his environment, including subjective and objective living conditions. ${ }^{25}$

\section{Well-being}

Well-being as a concept was identified in three papers. However, there was no specific definition of the concept. ${ }^{21,24,26}$

\section{Unmet needs}

The most frequent concept found was (un)met needs, which appears in four of the eight studies. ${ }^{18-20,23} \mathrm{~A}$ need was defined as a situation in which one experiences difficulty in the social, physical, psychological and environmental domains. ${ }^{19,23}$ Unmet needs were not clearly explained in the remaining two articles. ${ }^{18,20}$

\section{Design}

Out of the total of nine studies, five were crosssectional $18,20,22,25,26$ and three were longitudinal,19,21,23 with follow-up periods ranging from one year ${ }^{21,23}$ to two years; ${ }^{19}$ and one study used qualitative analysis of interviews. ${ }^{24}$ Just one paper, studying a therapeutic gardening intervention, included a baseline and followup evaluation. ${ }^{21}$

\section{Sample}

Four out of nine studies were conducted in the Netherlands, ${ }^{18-20,23}$ three in the United Kingdom ${ }^{21,24,26}$ one in Norway ${ }^{22}$ and one in Colombia. ${ }^{25}$ Samples included both genders in all studies. Four studies used the sample from the same database as the NeedYD-study ${ }^{18-20,23}$ although approaches and analysis of the data differed with different research questions.

Most of the papers, seven of them, included many different causes of dementia, such as AD, vascular dementia, frontotemporal dementia, mixed dementia, dementia with Lewy Bodies and dementia due to other causes. ${ }^{18-22,24,26}$

One study included only one person with $A D$ and his wife. ${ }^{23}$ Another study included three groups: middleaged adult carriers and non-carriers of mutation E280A in the Presenilin 1 gene for Early Onset Familial AD and healthy elderly people. ${ }^{25}$ Two articles evaluated only people with YOD. ${ }^{20,21}$ Four studies assessed people with YOD and their caregivers. ${ }^{18,19,23,26}$ One study included only caregivers ${ }^{22}$ and another one assessed a group of descendants who were not primary caregivers. ${ }^{24}$ None of the studies were randomized.

\section{Measurements}

Quality of life was assessed using the Quality of Life-Alzheimer Disease scale (QoL-AD), which covers 13 domains: physical health, energy, mood, living situation, memory, family, marriage, friends, chores, fun, money, self, and life as a whole. ${ }^{18,22}$ One study adopted the Dutch version of The RAND-36 Health Survey and used this scale in addition to the QoL-AD. This instrument consists of 36 questions to evaluate five mental and three physical domains: role limitations caused by emotional problems, social functioning, emotional well-being, vitality, general health perception, physical functioning, 
and role limitations caused by physical health problems and pain. ${ }^{18}$ The World Health Organization Quality of Life instrument-Abbreviated version (WHOQOL-Bref), used in one study has four domains: physical and psychological health, social relations and ambient. ${ }^{25}$

The assessment instrument most frequently used to measure unmet needs was the Camberwell Assessment of Need for the Elderly (CANE), a semi-structured interview consisting of 24 domains that cover social, physical, psychological, and environmental needs of PwD, as well as psychological needs of the caregiver. ${ }^{18-20,23}$ This instrument was used in all four Dutch studies.

Finally, one study adopted the Bradford Well-being Profile, based on observations taken by staff members, although well-being indicators were not reported in the article. ${ }^{21}$ One study did not have any specific instrument to assess QoL, well-being or (un)met needs, but used open interviews ${ }^{24}$ and another one did not specify the instruments used but mentioned the use of a health needs assessment, a postal survey and semi-structured interviews. ${ }^{26}$

\section{Findings}

\section{QoL}

One study found that QoL was not influenced by carrying the mutation E280A in gene Presenilin 1 for early onset familial AD. ${ }^{25}$ The health-related QoL (HRQoL) of people with YOD was not associated with unmet needs, but was associated with depression. ${ }^{18}$ People with YOD self-reported significantly higher scores than the QoLAD proxy scores assessed by caregivers. ${ }^{18}$ Carers rated their own HRQoL lower than the general population and unmet needs were related to several domains of caregiver HRQoL. ${ }^{18}$ Older age of the carer was associated with an increase in the total score of QoL and people with YOD having better disease awareness was associated with better QoL in their carers. ${ }^{22}$

\section{Unmet needs}

Two studies suggested similar findings regarding people with YOD, since relationships were detected between unmet needs and daytime activities, lack of companionship, performing tasks that depend on eyesight or hearing and difficulties with memory in both studies, ${ }^{18,19}$ but poor information, mobility and psychological distress were also associated with unmet needs in only one of these two studies. ${ }^{19}$ Other issues associated with unmet needs were prolonged time to diagnosis, lack of available health services, and strain of dedication to care versus the caregiver's own future perspective. ${ }^{23}$ One study suggested that there was no association between unmet needs and psychotropic drug use. ${ }^{20}$ People with YOD reported fewer unmet needs than did their caregivers, but both groups reported similar areas in which they perceived needs. The number of unmet needs in both cases decreased over time as dementia progressed. ${ }^{19}$

\section{Well-being}

In one study, people with YOD described their distress at losing their abilities to read, write, converse and take part in everyday life. ${ }^{26} \mathrm{~A}$ therapeutic gardening program was associated with a renewed sense of purpose and increased well-being in people with YOD. ${ }^{21}$ One study found a relationship between the well-being of children whose parents had YOD and delayed diagnosis and the difficulty of dealing with confused behaviors in agile, physically well adults. ${ }^{24}$ Most of the carers reported their well-being as poor or very poor and their well-being was perceived as worse depending on the duration of caring. ${ }^{26}$

\section{Discussion}

To the best of our knowledge, this is the first review that has systematically investigated factors associated with QoL and related concepts, such as wellbeing and unmet needs, in YOD. A primary concern is related to the unclear definitions of the concepts in the studies. ${ }^{18,20-22,24,26}$ Especially with regard to YOD, there is a need to understand the effect of the disease on both people with dementia and on caregivers' functioning with regard to their phase in life, which may include specific aspects of QoL, well-being and unmet needs. The lack of clear definitions exposes the need for more research in the area, including in order to better delineate these concepts with respect to YOD.

The great majority of studies, with a single exception, ${ }^{25}$ were conducted in developed countries in Europe. Additionally, four of the European studies were conducted by the same research group and used the same database, ${ }^{18-20,23}$ which can lead to cultural bias. It is necessary to increase the amount of information available and conduct research into YOD in different cultural backgrounds to better understand the particularities of the disease, including cultural contexts. For international validation of findings, other populations need to be studied.

Most of the papers included patients with different causes of dementia (i.e. Alzheimer's disease, Vascular Dementia, Frontotemporal Dementia, Lewy Body Dementia and Alcohol Related Dementia), indicating heterogeneous samples. The different etiologies have distinct symptoms and disease progression differs, 
possibly impacting the QoL of people with YOD and carers in varying ways. Only Rosness et al., ${ }^{22}$ who included dementia cases with different causes, compared QoL in carers of patients with Alzheimer's disease with non-Alzheimer's forms of dementia. In that study, people with Alzheimer's disease had been ill for shorter periods, had a more preserved consciousness of their condition and exhibited fewer behavioral disturbances than people with non-Alzheimer's disease. Family carers of people with Alzheimer's disease were less depressed than carers of those with dementia of other etiologies. ${ }^{22}$ The inclusion of heterogeneous dementia etiologies may negatively impact the consistency of the results for outcomes related to the QoL of people with YOD and their caregivers.

None of the studies included compared QoL in patients with YOD and LOD. We can assume that people with YOD have specific clinical and psychosocial symptoms and needs that may impact QoL differently. What differences might emerge in their QoL as a result? This is a knowledge gap in the field. Further studies should take into consideration the urgent need to better understand the differences between QoL in patients with YOD and LOD, in order that interventions can be developed that are properly designed to suit each of these two patient groups.

Evaluation instruments are another challenging area. Two studies reported that the inability of a large proportion of people with YOD to complete the assessment instruments was a limitation. ${ }^{18,19}$ Disease progression is faster in YOD than in LOD, and the instruments used to assess QoL, well-being and unmet needs that are widely used for LOD patients may not be appropriate for patients with YOD and their caregivers. Future research should focus on developing specific instruments for YOD. The validity of self-reported QoL in dementia has been exhaustively studied in LOD. However, considering the particularities of YOD, it is necessary to expand studies of the perspective of people with YOD of their own QoL. Bakker et al. ${ }^{18}$ found that the HRQoL of people with YOD was not associated with unmet needs. However, their assessment was only based on caregivers' reports. The caregiver's perspective may not represent the needs of people with YOD. ${ }^{18}$ Six studies evaluated the QoL of people with YOD ${ }^{18-21,23,26}$ and four of them took into account selfreported $\mathrm{HRQOL}$, well-being or unmet needs, rather than considering the opinion of the caregiver only. ${ }^{18,19,23,26}$ The validity of self-reporting is a critical issue in assessment of QoL in dementia. Many studies demonstrate that dementia severity, neuropsychiatric symptoms, cognitive impairments, and awareness of disease may influence self-rated QoL in people with dementia. ${ }^{15}$ It would be useful if studies of the QoL of people with YOD always took into consideration self-reported ratings, in order to clarify the differences between QoL assessments in LOD and YOD.

Attention must be brought to bear on how best to support people with YOD and their families. Delayed diagnoses and the use of support services in these families, professional's lack of knowledge about YOD and limited availability of services are closely related to higher levels of unmet psychological needs in caregivers. ${ }^{18}$ Specific services for people with YOD are uncommon in most countries, ${ }^{23}$ and this population is often cared for by services designed for older people. ${ }^{21,23}$ Professionals may not be aware of the differences and people with YOD and their family members may not feel well-served in these institutions. ${ }^{20}$ When services were responsive to their individual needs, people with YOD exhibited fewer neuropsychiatric symptoms. ${ }^{26}$ This also enabled the caregiver to entrust others with the care of his relative and eventually led to an increase in well-being for both the person with dementia and the caregiver. ${ }^{23}$ This underlines the importance of early introduction of professional services in the caregiving trajectory in YOD. ${ }^{19}$

Only one study evaluated a clinical intervention with people with YOD and its effectiveness with regard to QoL. ${ }^{21}$ Further studies should compare YOD and LOD in order to establish their differences and effectiveness in terms of QoL.

This review has a limitation. The variety of study aims and methodologies makes it difficult to pinpoint key issues. It would seem to be appropriate that future research should focus on using clear and replicable methodologies to enable more comprehensive analysis.

\section{Future directions and conclusions}

We systematically investigated the factors associated with QoL and related concepts in patients with YOD. The review process highlighted a number of issues related to the direction of future research. It is necessary to develop and increase research in other countries, and among populations with different cultural backgrounds. Consideration should be given to conducting investigations with more homogeneous samples and use of a clear concept of QoL. This would help to validate findings and improve understanding of the QoL of patients with YOD and of their carers. Finally, it is also important to examine the differences in QoL between patients with YOD and LOD and their carers.

Young onset dementia has attained greater visibility as the number of people affected increases and it becomes an important social and public health problem. 2,4,27 However, many countries lack specific plans, services and support strategies for YOD. ${ }^{20}$ Without specific knowledge about the 
disease and its possible impacts on the QoL of patients and their families, services tend to underestimate the need for

\section{References}

1. Withall A, Draper B, Seeher K, Brodaty H. The prevalence and causes of younger onset dementia in Eastern Sydney, Australia. Int Psychogeriatr. 2014;26:1955-65.

2. Vieira RT, Caixeta L, Machado S, Silva AC, Nardi AE, Arias-Carrión $O$, et al. Epidemiology of early-onset dementia: a review of the literature. Clin Pract Epidemiol Ment Health. 2013;9:88-95.

3. Shankar N. Clinical profile of young-onset dementia: a study from Eastern India. Neurol Asia. 2008;13:103-8.

4. Cruz BS. Levantamento epidemiológico de demência pré-senil no instituto de psiquiatria e centro de doenças de Alzheimer da UFR] [monograph]. Rio de Janeiro: IPUB/UFR]; 2002. 18 p. Especialização em Psiquiatria.

5. Harvey RJ. Young onset dementia: epidemiology, clinical symptoms, family burden, support and outcome. London: Dementia Research Group; 1998.

6. Harvey RJ, Skelton-Robinson M, Rossor MN. The prevalence and causes of dementia in people under the age of 65 years. J Neurol Neurosurg Psychiatry. 2003;74:1206-9.

7. Jefferies K, Agrawal N. Early-onset dementia. Adv Psychiatr Treat. 2009; 15:380-8.

8. Werner P, Stein-Shvachman I, Korczyn AD. Early onset dementia: clinical and social aspects. Int Psychogeriatr. 2009;21:631-6.

9. Svanberg E, Spector A, Stott J. The impact of young onset dementia on the family: a literature review. Int Psychogeriatr. 2011:23:356-71.

10. Koopmans R, Rosness T. Young onset dementia - what does the name imply? Int Psychogeriatr. 2014;26:1931-3.

11. Moslow K. Early onset dementia: a national challenge, a future crisis. Washington: Alzheimer's Association; 2006.

12. van Vliet $D$, de Vugt ME, Köhler $S$, Aalten $P$, Bakker C, Pijnenburg $\mathrm{YA}$, et al. Awareness and its association with affective symptoms in young-onset and late-onset Alzheimer disease: a prospective study. Alzheimer Dis Assoc Disord. 2013;27:265-71.

13. Galinha IC, Ribeiro JLP. História e evolução do conceito de bemestar subjectivo. Psic Saude \& Doenças. 2005;6:203-14.

14. Lauriks S, Reinersmann A, Van der Roest HG, Meiland FJ, Davies RJ, Moelaert F, et al. Review of ICT-based services for identified unmet needs in people with dementia. Ageing Res Rev. 2007;6:223-46

15. Sousa MF, Santos RL, Arcoverde C, Simões P, Belfort T, Adler I, et al. Quality of life in dementia: the role of non-cognitive factors in the ratings of people with dementia and family caregivers. Int Psychogeriatr.2013;25:1097-105.

16. Berwig $M$, Leicht $H$, Gertz $H J$. Critical evaluation of self-rated quality of life in mild cognitive impairment and Alzheimer's disease-further evidence for the impact of anosognosia and global cognitive impairment. ] Nutr Health Aging. 2009;13:226-30. medical care and other health professionals, leaving many of these people underserved..$^{2,4,11}$

17. Moher D, Liberati A, Tetzlaff J, Itman DG; PRISMA Group. Preferred reporting items for systematic reviews and meta-analyses: the PRISMA statement. Ann Intern Med. 2009;151:264-9, W64.

18. Bakker $C$, de Vugt $M E$, van Vliet $D$, Verhey $F$, Pijnenburg YA Vernooij- Dassen $\mathrm{MJ}$, et al. Unmet needs and health-related quality of life in young-onset dementia. Am J Geriatr Psychiatry. 2014;22:1121-30.

19. Bakker $C$, de Vugt $M E$, van Vliet $D$, Verhey $F R$, Pijnenburg YA, Vernooij- Dassen $M J$, et al. The relationship between unmet care needs in young-onset dementia and the course of neuropsychiatric symptoms: a two-year follow-up study. Int Psychogeriatr. 2014;26:1991-2000.

20. Koopmans RT, Reinders R, van Vliet D, Verhey FR, de Vugt ME, Bor $\mathrm{H}$, et al. Prevalence and correlates of psychotropic drug use in community-dwelling people with young-onset dementia: the NeedYD-study. Int Psychogeriatr. 2014;26:1983-9.

21. Hewitt P, Watts C, Hussey J, Power K, Williams T. Does a structured gardening programme improve well-being in young-onset dementia? A preliminary study. Br J Occup Ther. 2013;76:355-61.

22. Rosness TA, Mjorud M, Engedal K. Quality of life and depression in carers of patients with early onset dementia. Aging Ment Health. 2011;15:299-306.

23. Bakker $C$, de Vugt ME, Vernooij-Dassen $M$, van Vliet $D$, Verhey FR, Koopmans RT. Needs in early onset dementia: a qualitative case from the NeedYD study. Am J Alzheimers Dis Other Demen. 2010;25:634-40.

24. Allen J, Oyebode JR, Allen J. Having a father with young onset dementia: the impact on well-being of young people. Dement. 2009;8:455-80.

25. Herrera MCZ, Alzate MEL, Marín CMV, Gómez JAS, Acevedo DCA, Restrepo FL, et al. Autovaloración de calidad de vida y envejecimiento em adultos com riesgo de Alzheimer. Invest Educ Enferm. 2008:26:24-35.

26. Williams T, Dearden AM, Cameron IH. From pillar to post - a study of younger people with dementia. Psychiatr Bull. 2001;25:384-7.

27. Engelhardt E, Laks J, Dourado MCN, Mezzasalma MAU, CarvalhoPinto M, Chalita-Gomes $A$, et al. Demência pré-senil: impacto psicossocial. Rev Bras Neurol. 2002;38:5-11.

\section{Correspondence:}

Maria Alice Tourinho Baptista

Rua Ministro Viveiros de Castro, 66/1103, Copacabana

22021-010 - Rio de Janeiro, RJ - Brazil

Tel.: +55 (21) 99481.6666

E-mail: alicetb@ig.com.br 